\title{
Corrigendum: Immune Responses to Gametocyte Antigens in a Malaria Endemic Population - The African falciparum Context: A Systematic Review and Meta-Analysis
}

\author{
Michelle K. Muthui ${ }^{1 *}$, Alice Kamau ${ }^{1}$, Teun Bousema ${ }^{2,3}$, Andrew M. Blagborough ${ }^{4,5}$, \\ Philip Bejon ${ }^{1,6}$ and Melissa C. Kapulu ${ }^{1,6}$ \\ ${ }^{1}$ Department of Biosciences, KEMRI-Wellcome Trust Programme, Kilifi, Kenya, ${ }^{2}$ Immunology and Infection Department, \\ London School of Hygiene and Tropical Medicine, London, United Kingdom, ${ }^{3}$ Radboud Institute for Health Sciences, \\ Radboud University Medical Center, Nijmegen, Netherlands, ${ }^{4}$ Department of Life Sciences, Imperial College London, \\ London, United Kingdom, ${ }^{5}$ Department of Pathology, University of Cambridge, Cambridge, United Kingdom, ${ }^{6}$ Nuffield \\ Department of Medicine, Centre for Tropical Medicine and Global Health, University of Oxford, Oxford, United Kingdom
}

Keywords: immunity, Plasmodium falciparum, gametocytes, Pfs230, Pfs48/45

\section{A Corrigendum on}

Immune Responses to Gametocyte Antigens in a Malaria Endemic Population-The African falciparum Context: A Systematic Review and Meta-Analysis

OPEN ACCESS

Edited and reviewed by: lan Marriott,

University of North Carolina at

Charlotte, United States

*Correspondence:

Michelle K. Muthui

mmuthui@kemri-wellcome.org

Specialty section:

This article was submitted to Microbial Immunology,

a section of the journal

Frontiers in Immunology

Received: 15 January 2020 Accepted: 19 February 2020 Published: 23 March 2020

Citation:

Muthui MK, Kamau A, Bousema T,

Blagborough AM, Bejon P and Kapulu MC (2020) Corrigendum: Immune Responses to Gametocyte

Antigens in a Malaria Endemic Population-The African falciparum

Context: A Systematic Review and Meta-Analysis.

Front. Immunol. 11:389. doi: 10.3389/fimmu.2020.00389 by Muthui, M. K., Kamau, A., Bousema, T., Blagborough, A. M., Bejon, P., and Kapulu, M. C. (2019). Front. Immunol. 10:2480. doi: 10.3389/fimmu.2019.02480

In the original article, there were errors in Tables 1, $\mathbf{2}$ and 3, and to the text. In Table $\mathbf{1}$, one of the two study sites from Amoah et al.'s study (Parasites \& Vectors, 2018) was erroneously excluded from the table hence the study was presented as one site, the age range of study participants from the Stone et al. (Nature Communications, 2018) study site "Hauts-Bassins (Burkina Faso)" was mistakenly indicated as "2-74" instead of " $5-14$ " years and the reference for Skinner et al. given as " 35 " instead of " 33 ". These errors have been corrected and the amended table appears in this article.

Furthermore, owing to the omission of the study site from Amoah et al.'s study, the figures quoted in the text on the overall number of study sites and the total number of study sites reporting seroprevalence to Pfs 230 and Pfs48/45 were incorrect. The total number of study sites for Pfs 230 was given as "14" instead of "15" and for Pfs48/45 given as "14" instead of "13". Also, we inadvertently provided the total number of individual study locations ("23") instead of the study sites-based on administrative region-("17") when providing a summary of the 12 studies that we included in the analysis. In addition, the citation for "Amoah et al." was was incorrectly cited as "Acquah et al." in the Results section, sub-section Pfs230, Seroprevalence, Paragraph 1.

These errors have been corrected and amendments made to the relevant result sections, given below.

Results section, sub-section Study Selection and Characteristics, Paragraph 1:

"The 12 studies were carried out across 17 study sites, majority of which were in West Africa (Burkina Faso, Senegal, Gabon, Cameroon, Ghana, and Mali) with only one study site in East Africa (Tanzania) and two study sites in Southern Africa (Zimbabwe) (Table 1). Ten articles (from 15 study sites) measured responses to Pfs 230 and nine articles (13 study sites) measured responses to Pfs48/45. Six studies were longitudinal studies spread over the malaria transmission season with all but one measuring responses to both Pfs 230 and Pfs48/45. Studies predominantly used ELISA as the immunoassay with only one study measuring responses using protein microarrays." 
TABLE 1 | Characteristics of studies included in the systematic review and meta-analysis.

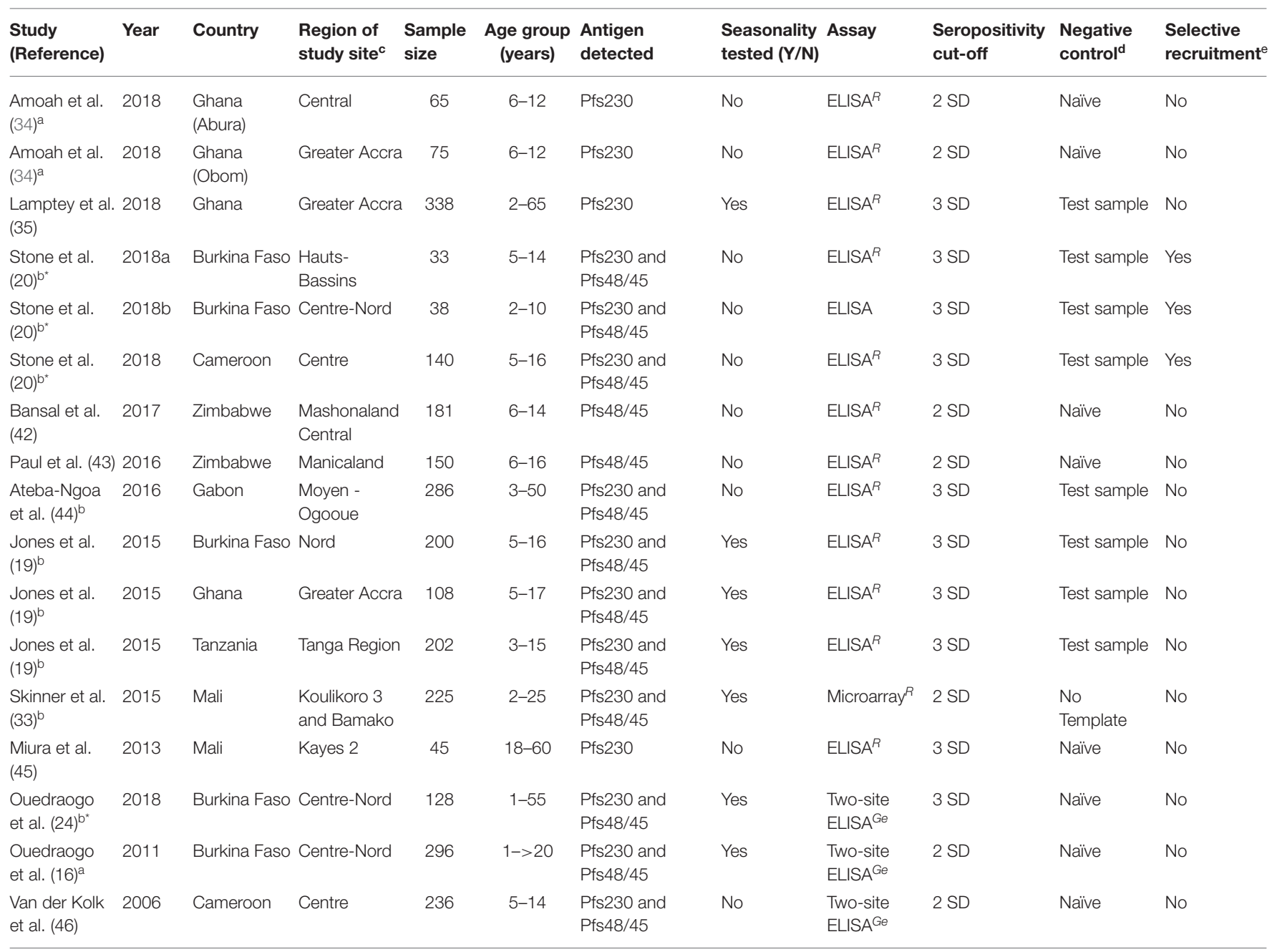

a Seroprevalence data provided by authors upon request.

${ }^{b}$ Seroprevalence data calculated from data provided by original authors, or from data available on public repositories.

$b^{*}$ Citation also includes citation of repository from which data was retrieved.

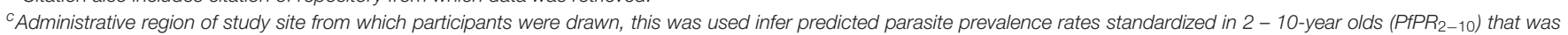
then used to assign transmission intensity at the time of sampling.

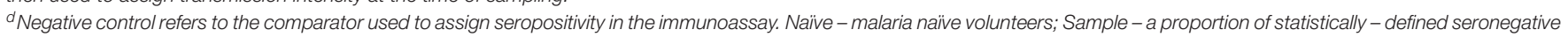
individuals; No template - a 'no DNA control' used to detect reactivity to the expression vector used to produce protein for the array.

e Selective recruitment refers to studies that only recruited parasite positive individuals for antibody measurements.

${ }^{R}$ Recombinant protein; ${ }^{G e}$ gametocyte extract.

$S D$, standard deviation.

TABLE 2 | Univariable meta-regression analysis of factors influencing reported seroprevalence to Pfs230.

\begin{tabular}{|c|c|c|c|c|c|c|c|}
\hline & $\begin{array}{l}\text { No. of studies } \\
\text { (No. of Sites) }\end{array}$ & Coefficient ( $\beta$ ) & Lower Cl & Upper Cl & $p$-value ${ }^{*}$ & Residual $I^{2}$ & $I^{2}$ change $(\%)$ \\
\hline \multicolumn{8}{|l|}{ Age } \\
\hline Adults & $6(6)$ & 0.21 & 0.05 & 0.38 & 0.04 & 95.36 & 2.09 \\
\hline $\begin{array}{l}\text { Asexual parasite } \\
\text { prevalence }\end{array}$ & $6(10)$ & -0.001 & -0.005 & 0.002 & 0.51 & 95.37 & 2.08 \\
\hline \multicolumn{8}{|l|}{ Transmission intensity } \\
\hline Mesoendemic (ref.) & $7(8)$ & & & & & & \\
\hline Hyperendemic & $6(7)$ & -0.06 & -0.23 & 0.11 & 0.51 & 96.18 & 1.25 \\
\hline
\end{tabular}


TABLE 2 | Continued

$\begin{array}{ccccccc}\begin{array}{c}\text { No. of studies } \\ \text { (No. of Sites) }\end{array} & \text { Coefficient }(\beta) & \text { Lower } \mathrm{Cl} & \text { Upper } \mathrm{Cl} & p \text {-value* } & \text { Residual } l^{2} & I^{2} \text { change }(\%)\end{array}$

\section{Season}

Dry (ref.)

Rainy

\section{Assay}

ELISA (ref.)

Microarray

Two-site ELISA

Antigen

Gametocyte extract (ref.)

Recombinant protein

Antigen concentration ${ }^{+}$

$$
\begin{aligned}
& 0.1 \mu \mathrm{g} / \mathrm{ml} \text { (ref.) } \\
& 1 \mu \mathrm{g} / \mathrm{ml}
\end{aligned}
$$

Seropositivity cut-off

$$
2 \text { SD (ref.) }
$$

$3 \mathrm{SD}$

$$
6(9)
$$$$
5(7)
$$

3 (3)

3 (3)

7 (12)

3 (7)

$3(4)$

4 (5)

6 (10)
0.07

0.31

0.12

$-0.06$

0.26

$-0.22$
$-0.12$

0.27

0.08

$-0.06$

0.55

0.29

$-0.25$

0.13

0.09

0.43

${ }^{*} p$-values adjusted using the Benjamini and Hochberg correction for multiple testing; values in bold $p<0.05$.

\begin{tabular}{|c|c|c|c|c|c|c|c|}
\hline & $\begin{array}{l}\text { No. of Studies } \\
\text { (No. of Sites) }\end{array}$ & Coefficient ( $\beta$ ) & Lower Cl & Upper Cl & $p$-value & Residual $I^{2}$ & $I^{2}$ change $(\%)$ \\
\hline \multicolumn{8}{|l|}{ Age } \\
\hline Adults & $4(4)$ & 0.07 & -0.12 & 0.27 & 0.49 & 94.90 & -0.18 \\
\hline $\begin{array}{l}\text { Asexual parasite } \\
\text { prevalence }\end{array}$ & $4(8)$ & -0.003 & -0.006 & 0.0003 & 0.11 & 91.41 & 3.96 \\
\hline Hypoendemic (ref.) & $1(1)$ & & & & & & \\
\hline Mesoendemic & $5(6)$ & -0.47 & -0.89 & -0.06 & 0.11 & 93.91 & 0.87 \\
\hline Hyperendemic & $5(6)$ & -0.38 & -0.80 & 0.04 & & & \\
\hline \multicolumn{8}{|l|}{ Season } \\
\hline Dry (ref.) & $4(6)$ & & & & & & \\
\hline Two-site ELISA & $3(3)$ & 0.09 & -0.07 & 0.24 & & & \\
\hline \multicolumn{8}{|l|}{ Antigen } \\
\hline Gametocyte extract (ref.) & $3(3)$ & & & & & & \\
\hline Recombinant protein & $6(10)$ & -0.01 & -0.19 & 0.17 & 0.91 & 94.91 & -0.19 \\
\hline \multicolumn{8}{|l|}{ Antigen concentration $^{+}$} \\
\hline $0.1 \mu \mathrm{g} / \mathrm{ml}$ (ref.) & $3(7)$ & & & & & & \\
\hline $1 \mu \mathrm{g} / \mathrm{ml}$ & $2(2)$ & 0.30 & 0.06 & 0.54 & 0.043 & 92.65 & 2.20 \\
\hline \multicolumn{8}{|l|}{ Seropositivity cut-off } \\
\hline $2 \mathrm{SD}$ (ref.) & $5(5)$ & & & & & & \\
\hline $3 \mathrm{SD}$ & $4(8)$ & -0.26 & -0.39 & -0.12 & 0.003 & 91.38 & 3.54 \\
\hline
\end{tabular}

+ Antigen concentration was only tested for studies using recombinant protein as antigen source.

$\mathrm{Cl}$, confidence interval; SD, standard deviation.

TABLE 3 | Univariable meta-regression analysis of factors influencing reported seroprevalence to Pfs $48 / 45$.

${ }^{*} p$-values adjusted using the Benjamini and Hochberg correction for multiple testing; values in bold $p<0.05$.

${ }^{+}$Antigen concentration was only tested for studies using recombinant protein as antigen source.

$\mathrm{Cl}$, confidence interval; SD, standard deviation. 
Results section, sub-section Pfs230, Seroprevalence, Paragraph 1:

"Ten studies from across 15 study sites in Africa analyzed immune responses to Pfs230. The range of seroprevalence estimates was quite wide, ranging from $6 \%$ reported by Stone et al. in Soumousso and Dande villages, Burkina Faso (20) to $72 \%$ reported by Amoah et al. (34) (Figure 2). Significant heterogeneity was observed between the studies $\left(I^{2}=97 \%\right.$; $95 \%$ CI: $96-98 \%$; $p<0.01)$ therefore, a pooled prevalence estimate was not calculated."

Results section, sub-section Pfs48/45, Seroprevalence, Paragraph 1:

"A total of 9 studies carried out over 13 study sites measured immune responses to Pfs $48 / 45$. The range of seroprevalence estimates reported was $0 \%$ from Stone et al.'s study sites in Burkina Faso (20) to $64 \%$ reported by Paul et al. from their study in the Makoni district in Zimbabwe (43). As with Pfs230,

\section{REFERENCES}

34. Amoah LE, Acquah FK, Ayanful-Torgby R, Oppong A, Abankwa J, Obboh EK, et al. Dynamics of anti-MSP3 and Pfs 230 antibody responses and multiplicity of infection in asymptomatic children from southern Ghana. Parasit Vectors. (2018) 11:5-13. doi: 10.1186/s13071-0172607-5 there was significant heterogeneity between the studies, $I^{2}=96 \%$ (95\% CI: 95-97\%), and hence no pooled estimate was calculated (Figure 3)."

Additionally, there were errors in Table 2 and Table 3, regarding the values for the No. of Studies (No. of Sites) under the variable Antigen. For Table 2, the numbers were switched around for gametocyte extract and recombinant protein and hence the numbers for Gametocyte extract read "7 (12)" instead of "3 (3)" and under the variable Recombinant protein read "3 (3)" instead of "7 (12)." For Table 3 one study was missing from the count hence the value for the No. of Studies (No. of Sites) under the variable Recombinant protein read "5 (10)" instead of "6 (10)." The corrected Tables 2 and 3 appear in this article.

The authors apologize for these errors and state that this does not change the scientific conclusions of the article in any way. The original article has been updated.

Copyright (c) 2020 Muthui, Kamau, Bousema, Blagborough, Bejon and Kapulu. This is an open-access article distributed under the terms of the Creative Commons Attribution License (CC BY). The use, distribution or reproduction in other forums is permitted, provided the original author(s) and the copyright owner(s) are credited and that the original publication in this journal is cited, in accordance with accepted academic practice. No use, distribution or reproduction is permitted which does not comply with these terms. 